\title{
Multigenic System Controlling Viral Systemic Infection Determined by the Interactions Between Cucumber mosaic virus Genes and Quantitative Trait Loci of Soybean Cultivars
}

\author{
Shizen Ohnishi, Issei Echizenya, Eri Yoshimoto, Kim Boumin, Tsuyoshi Inukai, and Chikara Masuta
}

Graduate School of Agriculture, Hokkaido University, 060-8589 Sapporo, Japan.

Accepted for publication 10 December 2010.

\begin{abstract}
Ohnishi, S., Echizenya, I., Yoshimoto, E., Boumin, K., Inukai, T., and Masuta, C. 2011. Multigenic system controlling viral systemic infection determined by the interactions between Cucumber mosaic virus genes and quantitative trait loci of soybean cultivars. Phytopathology 101:575582.

Soybean 'Harosoy' is resistant to Cucumber mosaic virus soybean strain C (CMV-SC) and susceptible to CMV-S strain D (CMV-SD). Using enzyme-linked immunosorbent assay and Northern hybridization, we characterized the Harosoy resistance and found that CMV-SC did not spread systemically but was restricted to the inoculated leaves in Harosoy. Harosoy resistance was not controlled by either a dominant or recessive

single gene. To dissect this system controlling long-distance movement of CMV in soybean, we constructed infectious cDNA clones of CMV-SC and CMV-SD. Using these constructs and the chimeric RNAs, we demonstrated that two viral components were required for systemic infection by the virus. The region including the entire $2 \mathrm{~b}$ gene and the $5^{\prime}$ region of RNA3 (mainly the $5^{\prime}$ untranslated region) together were required. By quantitative trait locus (QTL) analysis using an $\mathrm{F}_{2}$ population and the $\mathrm{F}_{3}$ families derived from Harosoy and susceptible 'Nemashirazu', we also showed that at least three QTLs affected systemic infection of CMV in soybean. Our study on Harosoy resistance to CMV-SC revealed an interesting mechanism, in which multiple host and viral genes coordinately controlled viral systemic infection.
\end{abstract}

Cucumber mosaic virus (CMV), the type member of the genus Cucumovirus, has a wide host range encompassing $>1,000$ species (21). The CMV genome consists of three positive-sense RNAs designated RNA1, -2 , and -3 . Five genes are located on either the genomic RNAs or two subgenomic RNAs (RNA4 and RNA4A). Genes 1a and 2a on RNA1 and -2, respectively, encode the proteins necessary for viral replication. The $2 \mathrm{~b}$ protein expressed from RNA4A functions as an RNA-silencing suppressor against the host defense system. The $3 \mathrm{a}$ gene encoding the movement protein and the coat protein $(\mathrm{CP})$ gene are located on RNA3; CP is expressed by RNA4.

Based on nucleotide sequence similarities, CMV isolates are classified into subgroups I and II, and subgroup I is further divided into IA and IB (22). The CMV soybean strains (CMV-S), previously called Soybean stunt virus, were first reported in Japan (14). Phylogenetic analysis based on the nucleotide sequence similarities of the $3 \mathrm{a}$ and $\mathrm{CP}$ genes showed that the CMV-S isolates formed a distinct cluster within CMV subgroup IB (8). Takahashi et al. (28) showed that CMV-S isolates had a relatively narrow host range and were classified into five strains (CMV-SA, -SB, -SC, -SD, and -SAE) based on their systemic infectivity to a large set of soybean (Glycine max (L.) Merr. subsp. max Ohashi) cultivars. Additionally, we previously reported that CMV-S infected not only cultivated soybean but also wild soybean (G. max subsp. soja (Sib. et Zucc.) Ohashi) (8). Both wild and cultivated soybean seem to have differentiated the CMV-strain-specific resistance genes, and resistance responses were determined by the specific combination of soybean cultivar and CMV-S strain $(8,28)$. However, the inheritance of those resistance has not yet been elucidated well.

Corresponding author: C. Masuta; E-mail address: masuta@res.agr.hokudai.ac.jp

doi:10.1094/PHYTO-06-10-0154

(c) 2011 The American Phytopathological Society
Resistance to CMV has been well characterized in other species $(12,13,27)$. For instance, the resistance associated with a hypersensitive reaction in Arabidopsis thaliana (L.) Heynh is induced by the interaction between the CP in CMV-Y and the coiled-coil nucleotide binding site leucine-rich repeat protein, which is encoded by $R C Y 1$ in the host $(26,27)$. In Arabidopsis, inaccessibility of CMV to host factors such as translation initiation factors $4 \mathrm{E}$ and $4 \mathrm{G}$ resulted in resistance (31-33). In addition to such resistance genes leading to major effects, quantitative trait loci (QTLs) concerned with partial resistance to CMV have also been reported for pepper (2-4). Some of those QTLs were associated with restriction of CMV long-distance movement (3). On the other hand, the viral CP $2 \mathrm{~b}$ and $3 \mathrm{a}$ genes have been reported to be involved in CMV long-distance movement $(6,15,30)$. Our previous work also demonstrated that the 3 a gene of CMV-SC was associated with viral long-distance movement in wild soybean (9).

In contrast to virus resistance depending on the interaction between resistance $(R)$ and avirulence $(A v r)$ genes, little is known about the molecular mechanism underlying virus resistance determined by the interactions between multiple host and viral factors. In this study, in order to dissect the system controlling longdistance movement of CMV in soybean, we analyzed the viral factors using infectious cDNA clones and chimeric RNAs and the host factors using QTL analysis. The results showed that multiple host and viral genes coordinately controlled viral systemic infection. Here, we describe a multigenic system that controls longdistance movement of CMV in soybean.

\section{MATERIALS AND METHODS}

Construction of infectious cDNA clones and chimeric RNAs. Infectious cDNA clones of CMV-SC and CMV-SD were made essentially as described by Suzuki et al. (25). Briefly, genomic RNAs were prepared from the purified virus, and full-length 
cDNAs were then synthesized by reverse-transcription polymerase chain reaction (RT-PCR) using the Takara RNA LA PCR kit (Takara, Otsu, Japan). The $5^{\prime}$ end primer has the T7 promoter sequence. The PCR products were then inserted into a plasmid vector (pUC119 or pBluescript) and in vitro transcription was performed to obtain infectious transcripts. Using those infectious clones, six pseudorecombinants were generated (Fig. 1). Chimeric viruses were also generated by domain swapping using the restriction sites. Those used between CMV-SC and CMV-SD for RNA3 (Fig. 2A and B) were BlnI (position 240 on CMV-SC RNA3), HpaI (943), and ApaI (1,166). For RNA2, FbaI (position 2,355 on CMV-SC RNA2) and $B \ln \mathrm{I}(2,948)$ were used (Fig. 2C and D). All recombinant clones were confirmed by sequencing.

Plant materials and infectivity tests. Eight soybean cultivars were used in this study (Table 1). The seed of these cultivars were provided by the National Institute of Agricultural Sciences Genebank, Tsukuba, Japan. A cross between 'Harosoy' and 'Nemashirazu' was made, and the $11 \mathrm{~F}_{1}$ plants and the $\mathrm{F}_{2}$ population, consisting of 100 plants, were developed. The $91 \mathrm{~F}_{3}$ families were also generated from the $F_{2}$ plants, and seven plants of each $F_{3}$ family were used for the genetic analysis. Plants were maintained in a greenhouse under either a 16-h photoperiod and temperatures of 24 to $26^{\circ} \mathrm{C}$ or natural conditions. Infectious transcripts synthesized from the constructs mentioned above were first used to inoculate Nicotiana benthamiana L., and the propagated virus was then purified. The first pair of true leaves of soybean or cotyledons of cucumber (Cucumis sativus L.) were dusted with carborundum and rub inoculated with the purified virus at $10 \mathrm{mg} / \mathrm{ml}$. The infection of the virus in all the inoculated leaves was confirmed by enzyme-linked immunosorbent assay (ELISA) with anti-CMV polyclonal antibody (Japan Plant Protection Association, Tokyo). The systemic infection of the virus was investigated at uninoculated upper leaves by ELISA.

Northern blot analysis. Total RNA was extracted by a conventional sodium dodecyl sulfate-phenol method (1), separated in a $1 \%$ formamide-denaturing gel, and blotted onto the Hybond $\mathrm{N}+$ membrane (GE Healthcare UK, Little Chalfont, UK). The applied RNA ( $1 \mu \mathrm{g} /$ lane) was confirmed by ethidium bromide staining of rRNAs. The $3^{\prime}$ region ( $\approx 300$ nucleotides) of CMV RNA3 was used as a probe after digoxigenin (DIG)-dUTP (Roche Diagnostics, Tokyo) was incorporated into the DNA fragment by PCR. For detection of the hybrid viruses, a 1:1 mixture of each probe synthesized from the $3^{\prime}$ regions of CMV-SC and CMV-SD was used. The blots were then treated with alkaline phosphataseconjugated anti-DIG gamma globulin and incubated in the solution containing the chemiluminescent substrate CDP star (Tropix, Maryland).

\begin{tabular}{|c|c|c|c|c|c|c|}
\hline \multirow[b]{3}{*}{ Virus name } & \multirow{2}{*}{\multicolumn{3}{|c|}{ Genome composition }} & \multicolumn{3}{|c|}{ Systemic infection at } \\
\hline & & & & \multicolumn{2}{|c|}{ Soybean cv. } & \multirow{3}{*}{$\begin{array}{c}\text { Nicotiana } \\
\text { benthamiana } \\
2 / 2\end{array}$} \\
\hline & RNA1 & RNA2 & RNA3 & Harosoy & Dekisugi & \\
\hline CMV-SD & & & & $14 / 14$ & $3 / 3$ & \\
\hline $\mathrm{CD} 2$ & 20002 & & & $11 / 12$ & $2 / 2$ & $2 / 2$ \\
\hline CD3 & 2010m & 20020 & & $0 / 12$ & $2 / 2$ & $2 / 2$ \\
\hline $\mathrm{CD} 1$ & $\mathrm{mem}$ & 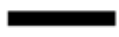 & $\mathrm{men}$ & $0 / 12$ & $2 / 2$ & $2 / 2$ \\
\hline CD4 & & & Emen & $0 / 4$ & $2 / 2$ & $2 / 2$ \\
\hline CD5 & & 200000 & & $0 / 4$ & $2 / 2$ & $2 / 2$ \\
\hline CD6 & & 0000 & स्यू & $0 / 4$ & $2 / 2$ & $2 / 2$ \\
\hline CMV-SC & 20200 & 20000 & स्या & $0 / 14$ & $1 / 1$ & $1 / 2$ \\
\hline
\end{tabular}

Fig. 1. Schematic representation of the genome structure and number of plants systemically infected by the pseudorecombinants constructed between $\mathrm{Cu}$ cumber mosaic virus (CMV)-SC and CMV-SD. Sequences corresponding to CMV-SC and CMV-SD are indicated with hatched and black boxes, respectively. Soybean cultivars 'Harosoy' and 'Dekisugi' and Nicotiana benthamiana $\mathrm{L}$. were inoculated with purified virus $(100 \mu \mathrm{g} / \mathrm{ml})$, and systemic infection was confirmed by enzyme-linked immunosorbent assay. Infectivity is expressed as the number of systemically infected plants/number of plants inoculated.
Preparation of soybean protoplasts and viral inoculation. Protoplasts were prepared from leaves of soybean plants grown in a growth chamber. The epidermal tissues were first scratched off with forceps, and the leaf tissues were then incubated in an enzyme solution containing $0.5 \mathrm{M}$ mannitol, 5\% Cellulase Onozuka R10 (Yakult Honsha, Tokyo), 0.5\% Pectolyase Y-23 (Seishin Pharmaceutical Co., Nagareyama, Japan), 0.1\% Driselase (Kyowa Hakko Kirin, Tokyo), and 1\% Macerozyme R10 (Yakult Honsha) at $30^{\circ} \mathrm{C}$ for 1.5 days. In all, $\approx 10^{6}$ protoplasts from 'Shiromame' or Harosoy were inoculated with $10 \mu \mathrm{g}$ of purified virus in the presence of $1 \%$ poly-L-ornithine. After 1 day of incubation in the dark at $28^{\circ} \mathrm{C}$, virus accumulation was determined by ELISA. For microscope observation, fluorescein isothiocyanate (FITC) labeled anti-CMV antibodies was also used (29). The protoplast experiments were repeated three times.

Hammer blotting and tissue printing. Hammer blots were prepared essentially as previously described (24,27). Soybean leaves (six plants total) were inoculated and detached 2 and 4 days postinoculation (dpi). The entire leaf was printed onto a
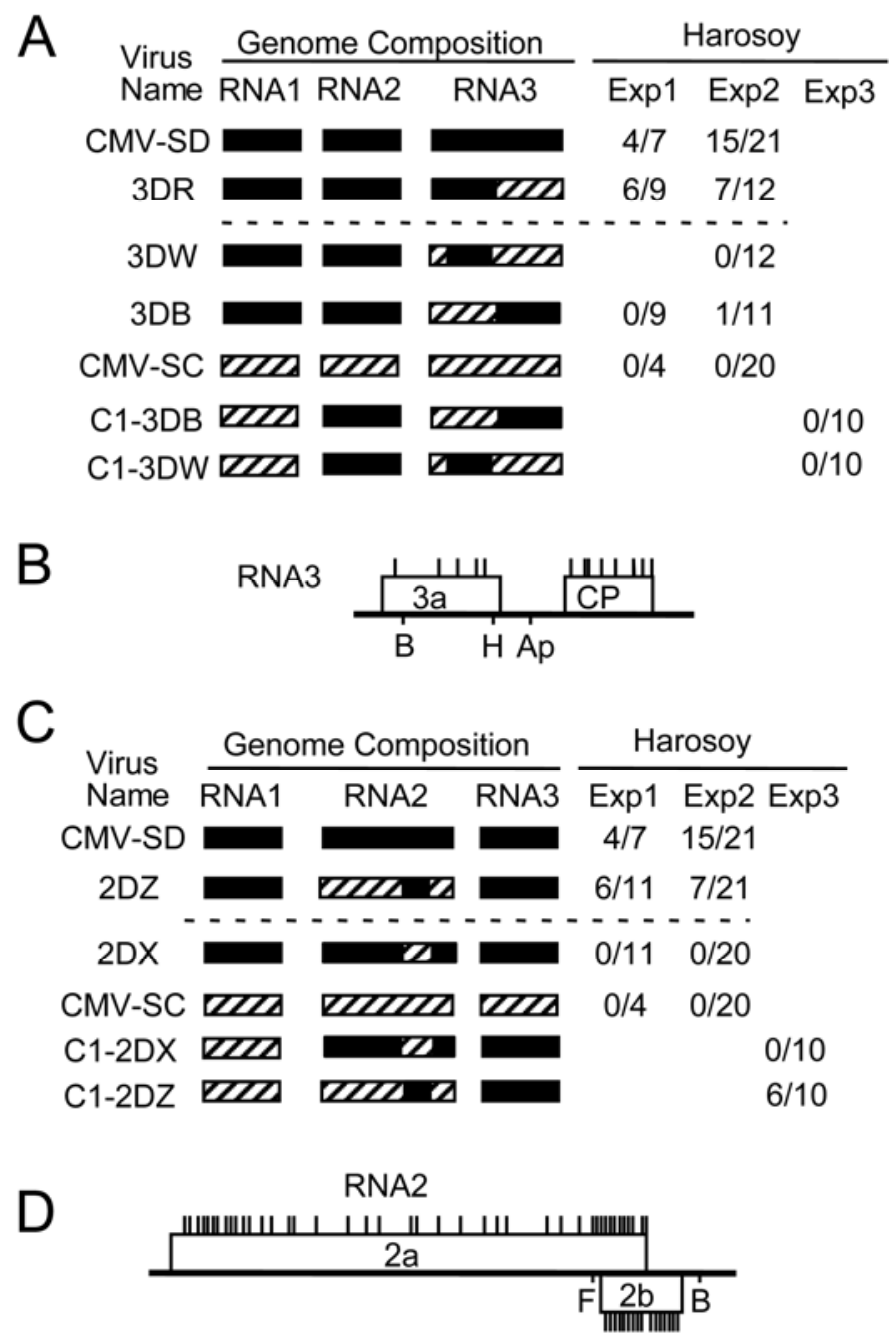

Fig. 2. Schematic representation of the genome structure and number of plants systemically infected by the chimeric recombinants constructed between Cucumber mosaic virus (CMV)-SC and CMV-SD. A, Chimeric RNA3 transcripts were inoculated with RNA1 and -2 of CMV-SD. B, Schematic map of the genome structure of RNA3. Restriction sites used to construct the recombinants are indicated by $\mathrm{B}(B \ln \mathrm{I}), \mathrm{H}(\mathrm{HpaI})$, and $\mathrm{Ap}(\mathrm{ApaI})$. C, Chimeric RNA2 transcripts were inoculated with RNA1 and -3 of CMV-SD. D, Schematic map of the genome structure of RNA2. Restriction sites used were $\mathrm{B}(B \ln \mathrm{I})$ and $\mathrm{F}(F b a \mathrm{I})$. Vertical bars above the open reading frames are positions of different amino acids between CMV-SC and CMV-SD. Inoculation results for parental viruses (CMV-SC and CMV-SD) were duplicated in $\mathrm{A}$ and $\mathrm{C}$. 
filter paper (grade no. 2) (Advantec, Tokyo) with a hammer, and the blots were incubated with anti-CMV primary antibody, then with goat anti-rabbit immunoglobulin alkaline phosphatase conjugate. The color was developed in a substrate solution containing nitroblue tetrazolium and 5-bomo-4-chloro-3-indolyl phosphate. Tissue prints on nitrocellulose membrane were prepared as previously described $(1,19)$. Sections of stem and petiole were sampled 14 dpi.

DNA extraction and simple sequence repeat markers. Total DNA was extracted from young leaves using MagExtractor (TOYOBO, Osaka, Japan). The primer sequences for the Sat and Satt simple sequence repeat (SSR) markers used in this study were obtained from the SOYBASE website (23). The PCR reaction mix contained 1 unit of ExTaq DNA polymerase (Takara, Tokyo), $10 \mathrm{mM}$ each dNTPs, $20 \mu \mathrm{M}$ each primer, $1 \times$ PCR buffer prepared for ExTaq, and $30 \mathrm{ng}$ of template DNA. The reactions were first subjected to $95^{\circ} \mathrm{C}$ for $2 \mathrm{~min}$. The PCR program was set for 33 cycles of $92^{\circ} \mathrm{C}$ for $1 \mathrm{~min}, 47^{\circ} \mathrm{C}$ for $1 \mathrm{~min}$, and $68^{\circ} \mathrm{C}$ for 1 min; and a final extension at $68^{\circ} \mathrm{C}$ for $5 \mathrm{~min}$. The PCR products were separated on $8 \%$ polyacrylamide gels, and the fragments were visualized with ethidium bromide staining.

QTL analysis. QTL analysis was carried out using the computer program Map Manager QTXb20 $(17,18)$. To detect

TABLE 1. Ratio of plants with systemic mosaic to total Cucumber mosaic virus (CMV)-inoculated plants of various soybean cultivars

\begin{tabular}{lcc}
\hline & \multicolumn{2}{c}{ Systemic infection $^{\mathrm{a}}$} \\
\cline { 2 - 3 } Cultivars & CMV-SD & CMV-SC \\
\hline Harosoy & $10 / 10$ & $0 / 12$ \\
Sakamotowase & $8 / 8$ & $18 / 18$ \\
Nemashirazu & $3 / 3$ & $9 / 9$ \\
Clark & $2 / 2$ & $4 / 4$ \\
Dekisugi & $12 / 13$ & $4 / 4$ \\
Williams & $2 / 2$ & $4 / 4$ \\
Tsurunoko & $6 / 7$ & $17 / 20$ \\
Shiromame & $7 / 8$ & $20 / 20$ \\
\hline
\end{tabular}

a Systemic infection was confirmed with enzyme-linked immunosorbent assay.
QTLs, we used a single-marker regression analysis. The significance of the association between the trait value and the expected contribution of the hypothetical QTL was tested using likelihood ratio statistics (LRS) (18). The LRS can be converted to a conventional base-10 logarithm of odds (LOD) score by dividing it by $2 \ln (10)$, and a LOD threshold of 3.0 was used to claim the presence of a QTL.

\section{RESULTS}

Viral genes responsible for compatibility with cultivars. Takahashi et al. (29) originally found five unique CMV isolates from soybean (CMV-SA, -SB, -SC, -SD, and -SAE) which were classified based on the systemic infectivity of soybean cultivars. For example, CMV-SC and CMV-SD can systemically infect some soybean cultivars but CMV-SC cannot systemically infect Harosoy and is restricted to the inoculated leaf (Table 1). To determine which viral RNA is involved in systemic movement, we generated six pseudorecombinants (CD1 to CD6) using fulllength cDNA clones of CMV-SC and CMV-SD (Fig. 1). The results of subsequent inoculations revealed that both RNA2 and -3 of CMV-SD were necessary to break the resistance of Harosoy because only CD2, which carried RNA1 from CMV-SC and RNA2 and -3 from CMV-SD, was capable of systemic infection. To analyze the gene or genes involved in Harosoy resistance in detail, we further created several chimeric viruses (Fig. 2).

The results of the RNA3 chimera showed that the 5' end region of RNA3 from CMV-SD (nucleotides 1 to 240) was necessary for systemic infection (Fig. 2A). In comparison with 3DR, 3DW has a single amino acid difference in the $3 \mathrm{a}$ open reading frame (ORF) and 15 different nucleotides in the $5^{\prime}$ untranslated region (UTR). The results of the RNA2 chimera (Fig. 2C) showed that the region containing the $3^{\prime}$ end of the $2 \mathrm{a}$ ORF and the entire $2 \mathrm{~b}$ gene between the $F b a \mathrm{I}$ and $B \ln \mathrm{I}$ sites were necessary. The differing amino acids are concentrated within the domain that contains this region (Fig. 2D); 18 positions differed between 2DZ and $2 \mathrm{DX}$ in the $2 \mathrm{~b}$ gene, and 19 amino acids were changed in the overlapped $2 \mathrm{a}$ gene. Thus, we conclude that both the 5 ' end region

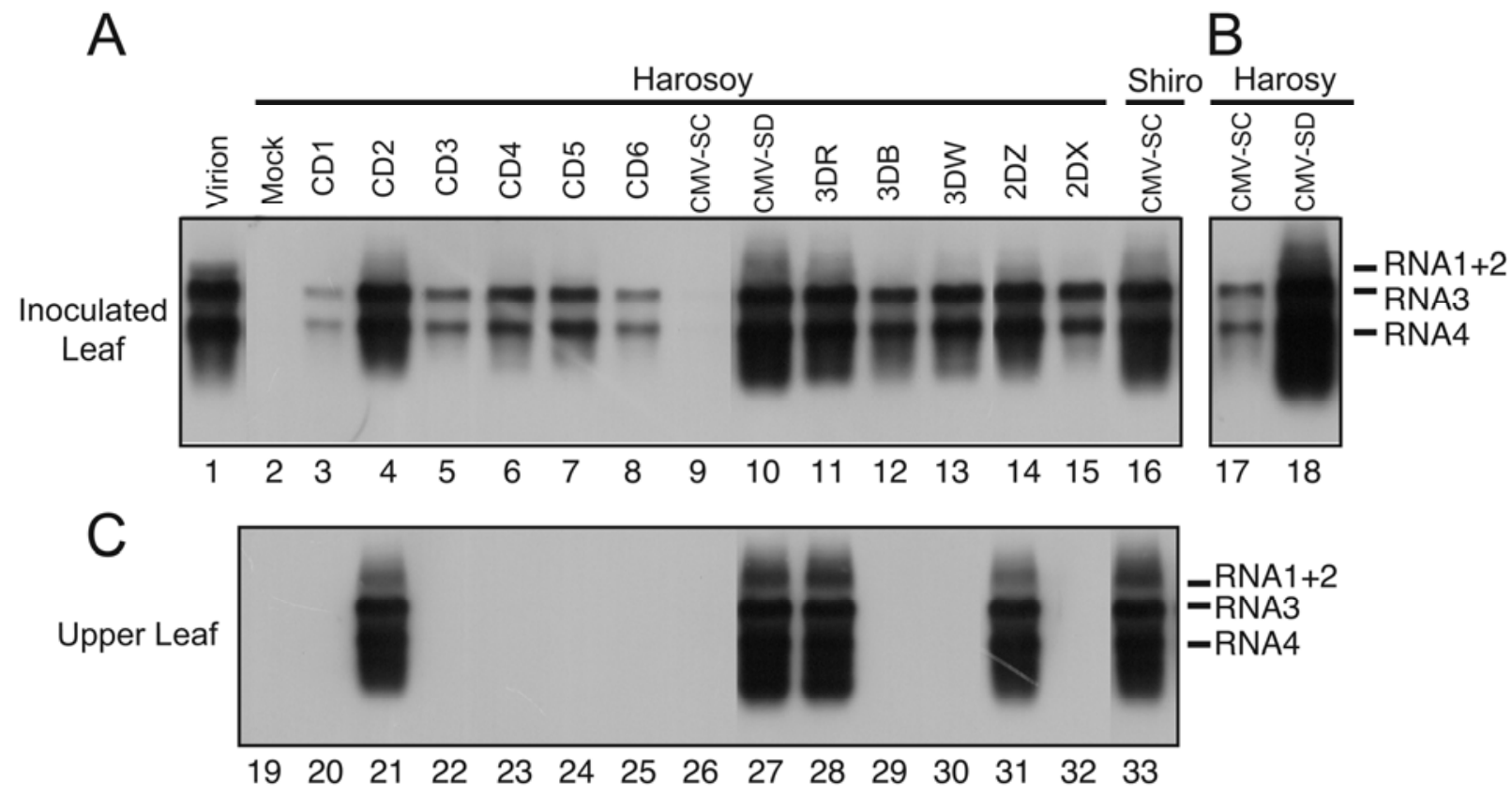

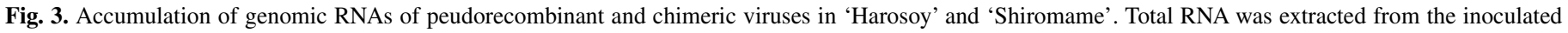

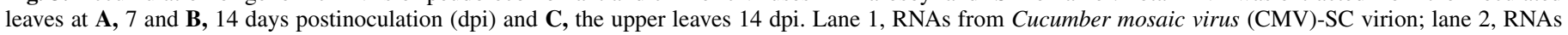

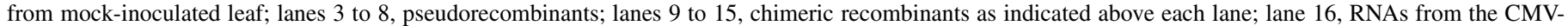

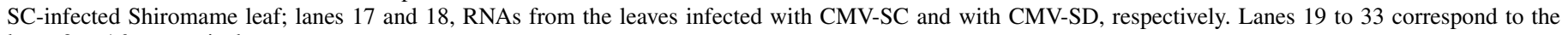
lanes 2 to 16 , respectively. 


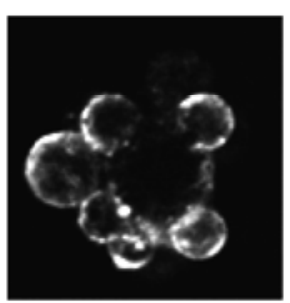

CMV-SC

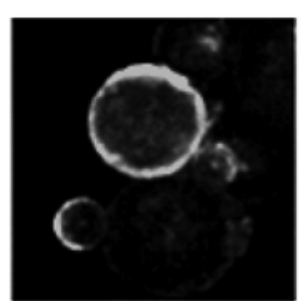

CMV-SD $\underline{0} \mathrm{~h}$ incubation (Control)

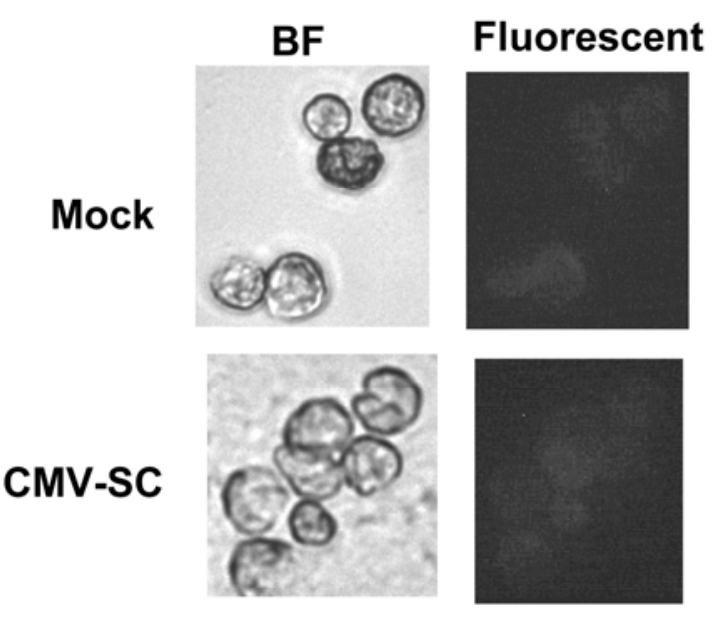

B

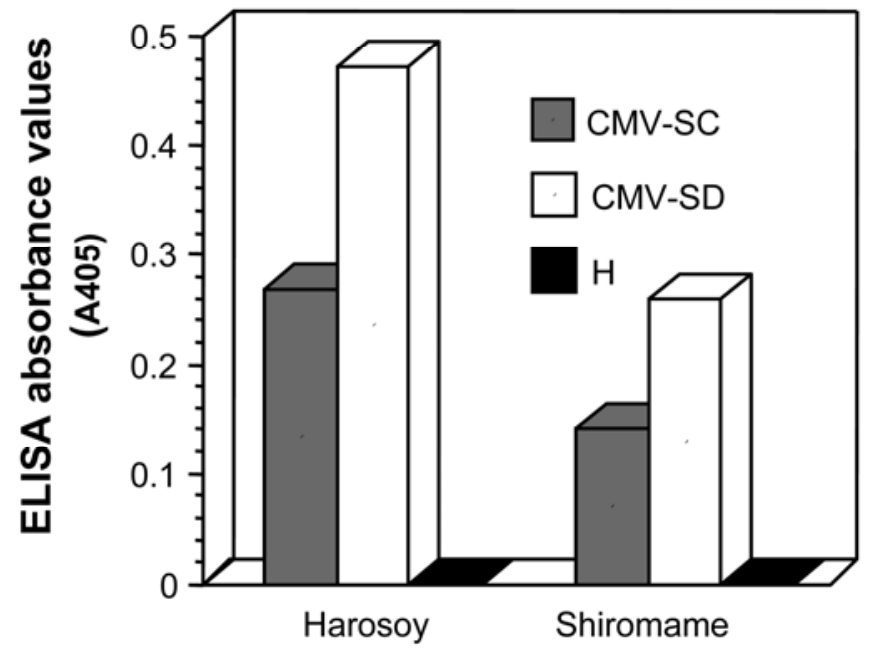

Fig. 4. Susceptibility of protoplasts from 'Harosoy' and 'Shiromame' to infection with Cucumber mosaic virus (CMV)-SC or with CMV-SD. Results were reproducible in four independent experiments; this figure is representative. Protoplasts $\left(10^{6}\right)$ were inoculated with $10 \mu \mathrm{g}$ of purified virus in the presence of poly-L-ornithine. A, Percentage of infected protoplasts was determined by fluorescein isothiocyanate (FITC)-fluorescent antibody staining (80 to $90 \%$ for all treatments). There was little difference among the experimental groups in the number of surviving protoplasts. As a control, the soybean protoplasts that were stained with FITC-fluorescent antibody immediately after CMV-SC inoculation ( $0 \mathrm{~h}$ of incubation) were shown. Note that there is no fluorescence in the virus-treated cells. BF, blight filed. B, Viral accumulation after incubation for $24 \mathrm{~h}$ was assayed by enzyme-linked immunosorbent assay (ELISA). of RNA3 (mostly in the UTR) and the region in RNA2 including the $3^{\prime}$ end of the $2 \mathrm{a}$ ORF and the entire $2 \mathrm{~b}$ gene are responsible for systemic infection in Harosoy.

Viral accumulation of the pseudorecombinant and chimera in Harosoy. When a resistant melon plant was inoculated with CMV, the relative amount of the viral RNAs was sometimes affected (7). Thus, we used RNA blotting to analyze viral accumulation of the pseudorecombinant and chimeric viruses used for the present study. The viruses differentially accumulated in the inoculated leaves. In the inoculated leaves of Harosoy, the viruses that could systemically infect (CMV-SD, CD2, 3DR, and 2DZ) tended to accumulate more efficiently than did viruses that failed to move to the upper leaves (CMV-SC, CD1, CD3, CD4, CD5, CD6, 3DB 3DW, and 2DX) (Fig. 3). Additionally, the presence of RNA2 and -3 from CMV-SD increased the level of virus in the inoculated leaves (Fig. 1) (e.g., CD4 and CD5 against CD6). Interestingly, CMV-SC accumulated to high levels in the inoculated leaves of Shiromame but to very low levels in Harosoy.

Protoplast inoculation. To determine whether CMV-S can multiply in protoplasts isolated from resistant Harosoy, protoplasts were prepared from leaves and inoculated with CMV-SC and CMV-SD. The infected protoplasts were stained with FITClabeled anti-CMV antibodies and observed under a microscope (Fig. 4A). The observation that $>80 \%$ of protoplasts were infected suggests that CMV-SC as well as CMV-SD are efficiently replicating in the Harosoy protoplats. Viral accumulation in protoplasts was then measured by ELISA using anti-CP antibodies $1 \mathrm{dpi}$. In four repeated experiments, the difference in relative accumulation levels of CMV-SC versus CMV-SD were similar between susceptible Shiromame and resistant Harosoy (Fig. 4B).

Localization of CMV-S strains in inoculated leaves. To detect virus localization in inoculated leaves, we used hammer blotting. Shiromame is a systemic host for both CMV-SC and CMV-SD, whereas CMV-SD can systemically infect Harosoy and CMV-SC is restricted to the inoculated leaves of Harosoy. We used a total of six plants and performed hammer blotting at 2 or 4 dpi. Even in the Harosoy leaves, there was little difference in the number and size of infection sites between CMV-SC and CMV-SD (Fig. 5). However, systemic movement was clearly detected in the CMV-SD-inoculated plants (Fig. 6). When Harosoy was inoculated with CMV-SD, we observed that the veins in the inoculated leaves were clearly stained with the antibodies 4 dpi. Similarly, the virus was detected all over the inoculated leaves 4dpi when CMV-SC was inoculated onto Shiromame.

Inheritance of CMV resistance in Harosoy at the level of long-distance movement. In Harosoy leaves, systemic movement of CMV-SC was inhibited. When CMV-SC was used to inoculate $\mathrm{F}_{1}$ plants derived from a cross between Harosoy and Nemashirazu, which is completely susceptible to CMV-SC, all the $\mathrm{F}_{1}$ plants tested were systemically infected (Table 2). Based on these results, we first hypothesized that the Harosoy resistance was controlled by a single recessive gene or two complementary genes (one was recessive and the other was dominant). However, the segregation ratio of the $F_{2}$ population was 36 resistant $(R)$ to 64 susceptible (S) plants, which fitted to neither the 1:3 nor 3:13 expected ratios (Table 2). The segregation ratio of the $\mathrm{F}_{3}$ families was 29 all R:25 segregating:37 all $\mathrm{S}$. This ratio also did not fit to either the $1: 2: 1$ or $1: 8: 7$ expected ratios (Table 2). To determine the chromosomal location of the CMV-SC resistance genes, we first tested 157 SSR markers distributed on the 20 soybean linkage groups (LGs) for polymorphism between the parental cultivars. Among 157 markers, 66 markers were polymorphic between the parents and 2 to 7 markers were distributed in each LG. By the linkage analysis using those SSR markers, loose linkages between the resistant trait and multiple SSR markers were detected, for instance, in LG M containing the QTL described later. However, the resistance locus was not well 
integrated on the map because the map distances between each marker locus and the resistance locus were not consistent with each other. Thus, the inheritance of the Harosoy resistance to CMV-SC could not be explained by simple Mendelian factors. Because the resistance for restriction of $\mathrm{CMV}$ long-distance movement in pepper was previously shown to be regulated by QTLs (3), we next performed a single-marker regression analysis to detect the QTLs for resistance to CMV-SC in Harosoy. In this QTL analysis, binary data for a resistant $(=1)$ or susceptible $(=0)$ response in the $F_{2}$ population were first used. This result showed
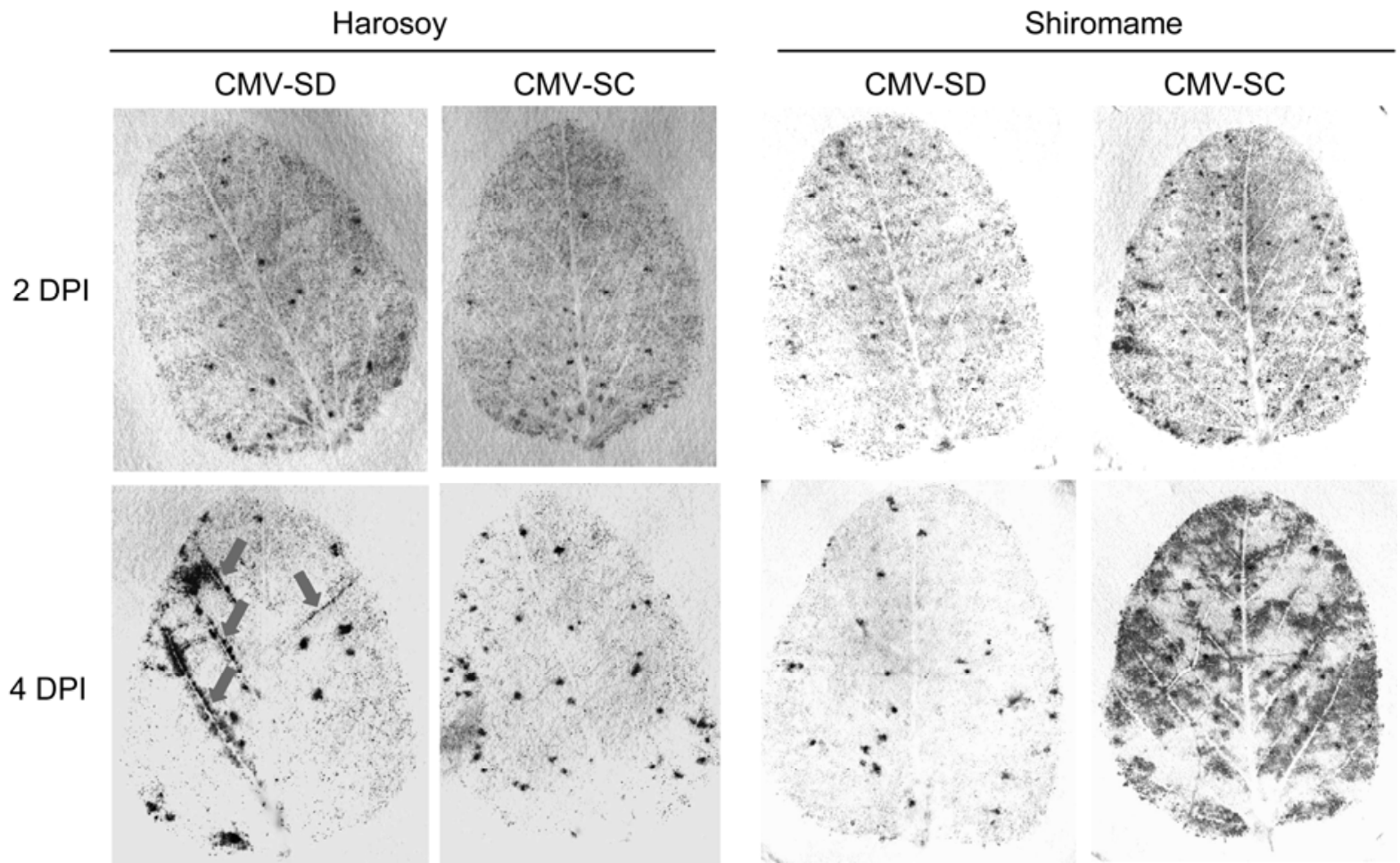

Fig. 5. Localization of Cucumber mosaic virus (CMV)-S in soybean leaves inoculated with CMV-SC or CMV-SD at 2 and 4 days postinoculation. Detection of coat protein (CP) in CMV-infected 'Harosoy'. Stained veins are indicated by a gray arrow. Detection of CP in CMV-infected 'Shiromame'. CMV-SC never moved to the upper leaves of Harosoy even after 1 month. The experiment was repeated three times, and results were reproducible.

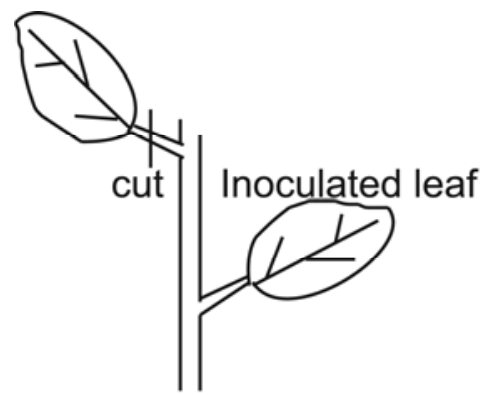

\section{H CMV-SD CMV-SC}
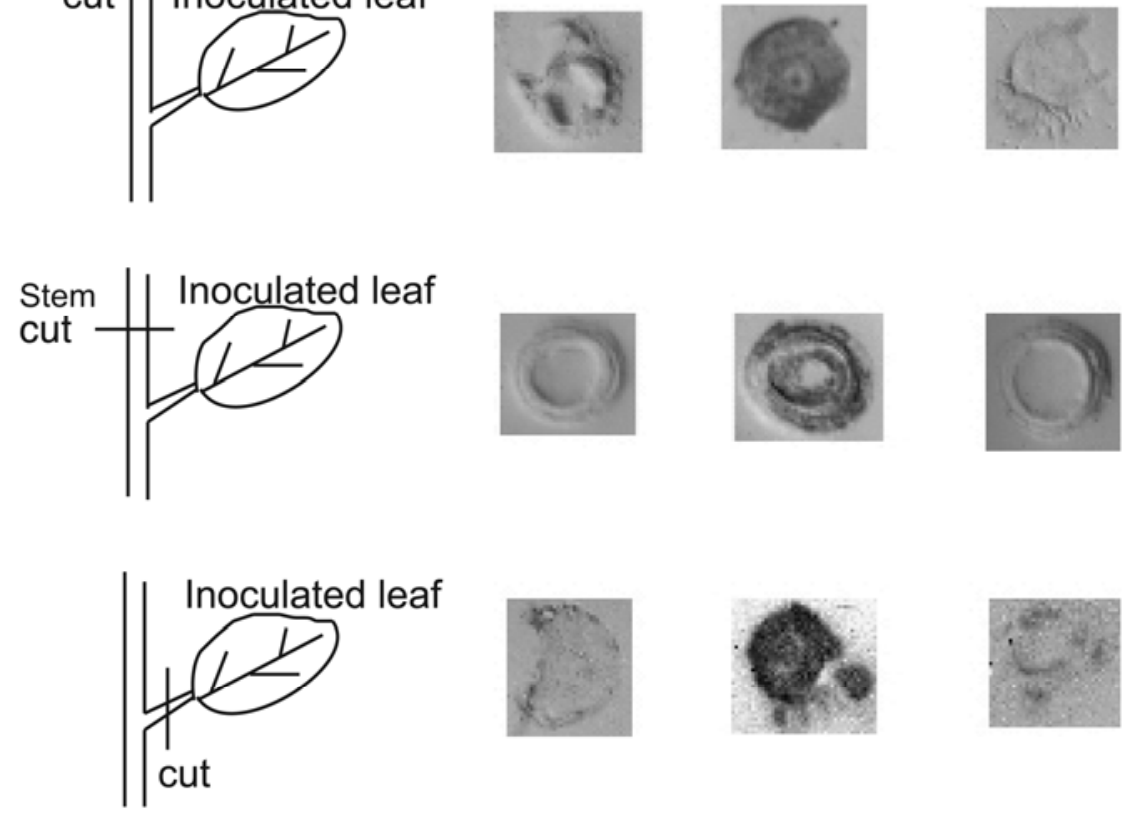

Fig. 6. Detection of viral coat protein in 'Harosoy' inoculated with Cucumber mosaic virus (CMV)-SC or CMV-SD 14 days postinoculation in petiole of an upper, uninoculated leaf; in main stem; and in petiole of inoculated leaf. 
that Satt184 on LG D1a and Satt567 on LG M were significantly associated with the resistance to CMV-SC. Additionally, three SSR markers (Sat_413, Sat_244, and Satt345 on LGs D1a, M, and $\mathrm{O}$, respectively) were shown to be potentially associated with the resistance (Table 3). Because the map distance between Sat_413 and Satt184 on LG-D1a and between Satt567 and Sat_244 on LG-M was estimated to be 9.6 and 25.8 centimorgans, respectively, we assumed that two loci were significantly associated with CMV resistance (one each of LG-D1a and -M) and a possible third on LG-O. SSR markers Satt184, Satt567, and Satt345 explained 16, 19, and $12 \%$ of phenotypic variance, respectively (Table 3), and all resistance alleles were derived from Harosoy. To confirm these results, the marker regression analysis was also carried out using the percentage of resistant plants within each $F_{3}$ family as phenotypic value for the parental $F_{2}$ plant. The distribution of the percentage of resistant plants per $F_{3}$ family was continuous and bimodal (Fig. 7). In this analysis, the two SSR markers, Satt567 and Satt345, were found to be potentially associated with Harosoy resistance to CMV-SC (Table 3). Although the LOD scores for both SSR markers were <3.0, these results supported the significance of the two QTLs on LGs $\mathrm{M}$ and $\mathrm{O}$ detected using the $\mathrm{F}_{2}$ population.

\section{DISCUSSION}

Plants have a network of counter-defense systems against pathogens. One such defense is controlled by dominant $R$ genes against pathogens having corresponding $A v r$ genes. In many pathosystems, $R$ and $A v r$ genes have been sought according to the gene-for-gene model (11). However, $R$ genes alone do not necessarily explain the observed resistance; rather, the majority of defense systems are likely determined by the balance of the interactions between multiple factors of host and pathogen. For the pathosystem of CMV, it has been quite difficult to find such a single, dominant resistance gene; they have been found for only a few specific CMV isolates $(12,13,27)$. In contrast, partial resistance to CMV controlled by multiple genes has been documented for a number of crops, including pepper and soybean $(2-4,8)$. If multiple host genes are involved in CMV resistance, it is conceivable that those genes coordinately operate at various steps which are governed by multiple viral genes during CMV infection. Little is known about the molecular mechanism underlying virus-host pathosystems based on multigenic resistance involving multiple host and viral factors. Along these lines, in this report, we tried to explain the pathosystem of CMV and soybean, characterizing the observed resistance based on the interactions between multiple factors of the host and the virus.

In the CMV-S-soybean pathosystem, we found that two viral factors, the $5^{\prime}$ end of RNA3/the $3 \mathrm{a}$ gene and the $3^{\prime}$ end of the $2 \mathrm{a}$ gene/the $2 \mathrm{~b}$ gene are together important for the resistance of Harosoy to CMV-SC. The 3a protein has been reported to be involved in long-distance movement as well as cell-to-cell movement (15). A single amino acid difference between SC and SD in the $3 \mathrm{a}$ protein of the $3 \mathrm{DW}$ construct may determine the phenotype. Even the 5' UTR may be able to affect the level of the 3a protein in infected cells; Yoshii et al. (31-33) previously reported that Arabidopsis mutations in eIF4E and 4G actually affected the $3 \mathrm{a}$ translation efficiency in a 5' UTR-sequencedependent manner.

The $2 \mathrm{a}$ gene encodes the viral replicase and is also necessary for viral movement (5). The $2 \mathrm{~b}$ protein is an RNA-silencing suppressor (16), interferes with SA-mediated virus resistance (10), and also has a role in viral movement (6). Therefore, it is likely that the nature of both $2 \mathrm{a}$ and $2 \mathrm{~b}$ proteins can determine the phenotypes in the soybean cultivars.

TABLE 3. Simple sequence repeat (SSR) marker loci associated with Cucumber mosaic virus (CMV)-SC resistance based on a single marker regression analysis ${ }^{\mathrm{a}}$

\begin{tabular}{lcccc}
\hline Data set $^{\mathrm{b}}$ & Linkage group & SSR marker & LOD & Var (\%) \\
\hline $\mathrm{F}_{2}$ binary data & D1a & Sat_413 & 2.65 & 12 \\
& D1a & Satt184 & 3.67 & 16 \\
& $\mathrm{M}$ & Satt567 & 4.36 & 19 \\
& $\mathrm{M}$ & Sat_244 & 2.58 & 12 \\
Resistant $\mathrm{F}_{3}$ & $\mathrm{O}$ & Satt345 & 2.62 & 12 \\
& $\mathrm{M}$ & Satt567 & 2.60 & 12 \\
& $\mathrm{O}$ & Satt345 & 2.15 & 10 \\
\hline
\end{tabular}

${ }^{a}$ SSR markers with a logarithm of odds (LOD) score $>2.0$ are indicated. Var $(\%)=$ percentage of phenotypic variance explained by individual markers.

${ }^{b}$ Binary data $(1$ or 0$)$ for $\mathrm{F}_{2}$ individuals and percentage of resistant plants within each $\mathrm{F}_{3}$ family.

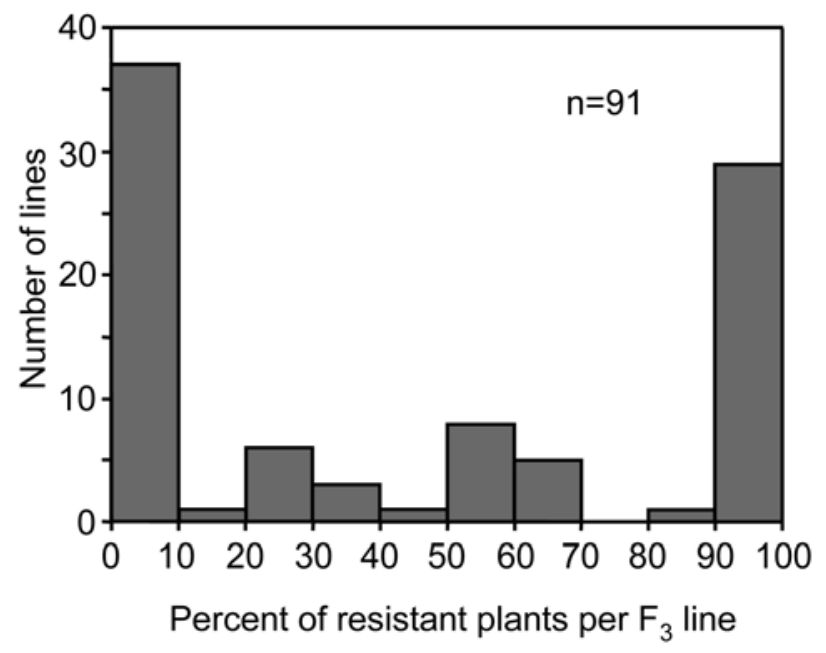

Fig. 7. Frequency distribution of the resistant/susceptible segregation ratio (R:S) for Cucumber mosaic virus (CMV)-SC resistance within each $\mathrm{F}_{3}$ line developed from the $F_{2}$ individuals of the cross between 'Harosoy' and 'Nemashirazu'. R:S is expressed as the percentage of resistant plants per line. In this experiment, none of the tested Harosoy plants were systemically infected; all Nemashirazu plants were systemically infected.

TABLE 2. Segregation of resistance phenotypes to Cucumber mosaic virus (CMV)-SC in an $\mathrm{F}_{2}$ population and the $\mathrm{F}_{3}$ families derived from a cross between resistant (R) 'Harosoy' and susceptible (S) 'Nemashirazu'a

\begin{tabular}{|c|c|c|c|c|c|c|c|c|}
\hline \multirow[b]{2}{*}{ Cultivar or cross } & \multirow[b]{2}{*}{ Generation } & \multicolumn{4}{|c|}{ No. of plants or lines } & \multirow[b]{2}{*}{ Expected ratio } & \multirow[b]{2}{*}{$\chi^{2}$} & \multirow[b]{2}{*}{$P$} \\
\hline & & $\mathrm{R}$ & Seg. & $\mathrm{S}$ & Total & & & \\
\hline Harosoy $(\mathrm{H})$ & $\ldots$ & 5 & - & 0 & 5 & $\ldots$ & $\ldots$ & $\ldots$ \\
\hline Nemashirazu (N) & $\cdots$ & 0 & - & 5 & 5 & $\cdots$ & $\cdots$ & $\cdots$ \\
\hline \multirow[t]{2}{*}{$\mathrm{H} \times \mathrm{N}$} & $\mathrm{F}_{2}$ & 36 & - & 64 & 100 & $1: 3$ & 6.45 & 0.011 \\
\hline & & & & & & $3: 13$ & 19.53 & $<0.01$ \\
\hline $\mathrm{H} \times \mathrm{N}$ & $\mathrm{F}_{3}$ & 29 & 25 & 37 & 91 & $1: 2: 1$ & 19.88 & $<0.01$ \\
\hline
\end{tabular}

\footnotetext{
${ }^{a}$ Reaction type of each plant was examined 3 weeks postinoculation. Systemic infection was confirmed with enzyme-linked immunosorbent assay. Seg. means
} that $\mathrm{R}$ and $\mathrm{S}$ plants are segregated within each $\mathrm{F}_{3}$ line. 
To find the operative points of the Harosoy resistance to viral infection, we conducted three experiments: protoplast inoculation, hammer blotting, and Northern blotting. Whether protoplasts were isolated from susceptible Shiromame or resistant Harosoy, there was little difference in relative accumulation of CMV-SC versus CMV-SD in Shiromame and Harosoy, suggesting that the resistance does not operate at the level of viral replication. We then analyzed infection sites of CMV-S in the inoculated leaves by hammer blotting. In the inoculated leaves of Harosoy, both CMV-SC and CMV-SD produced similar infection spots, suggesting that there was little difference in the initial infection and spread of the viruses to neighboring cells between CMV-SC and CMV-SD. The results of Northern blotting analyses indicated that the level of CMV-SD in the inoculated leaves was significantly higher than that of CMV-SC. However, there was little correlation between the accumulation level and the ability of the virus to move systemically in Harosoy. When these results are considered together, Harosoy resistance to CMV-SC appears to operate at the level of long-distance movement.

We showed here that Harosoy resistance to CMV-SC was controlled by multiple QTLs. The results of the marker regression analyses using the binary data for $\mathrm{F}_{2}$ individuals indicated that at least three QTLs on LGs D1a, M, and O were associated with CMV-SC resistance. Of the three QTLs, the QTL on LG D1a was not detected by the analysis using the percentage of resistant plants within each $\mathrm{F}_{3}$ line. Because the inoculation tests using the $\mathrm{F}_{2}$ population and the $\mathrm{F}_{3}$ families were done in the greenhouse under natural conditions, the effect of the QTL on LG D1a could have been masked by varying environmental conditions.

We showed that both the $5^{\prime}$ end of RNA3/the 3a gene and the $3^{\prime}$ end of the $2 \mathrm{a}$ gene/the $2 \mathrm{~b}$ gene together affected long-distance movement of the virus. Because the systemic movement of CMV$\mathrm{SC}$ was restricted in a cultivar (Harosoy)-specific manner, the products of the identified QTLs may interact directly with the CMV-SC proteins. At this stage, we are unable to identify any genes as concrete candidates for the QTLs because of limitation of the population size and the number of SSR markers used; however, they should be involved in viral systemic movement. For example, Requena et al. (20) previously reported that CMV mainly moved through cucumber sieve tubes as viral particles and that CMV particles interacted with the phloem exudate protein p48, which, thus, is easy to consider as one of the first candidates for the QTLs. However, in this case, the interactions between host and viral factors to restrict the CMV-SC systemic movement in the phloem seem to occur before CMV-SC enters the phloem in Harosoy plants. Because entire soybean genomic sequences are now available in the database, our efforts to identify the QTLs are underway. Considering that the corresponding viral factors have been identified, we may also find the QTL products involved in the Harosoy resistance by screening the binding proteins to the $3 \mathrm{a}, 2 \mathrm{a}$, and $2 \mathrm{~b}$ proteins of CMV-SC.

\section{ACKNOWLEDGMENTS}

This work was supported in part by a grant-in-aid for scientific research on scientific research (C) (12660037) from the Ministry of Education, Culture, Sports, Science and Technology.

\section{LITERATURE CITED}

1. Asaoka, R., Shimura, H., Arai, M., and Masuta, C. 2010. Aprogeny virus from a Cucumovirus pseudorecombinant evolved to gain the ability to accumulate its RNA-silencing suppressor leading to systemic infection in tobacco. Mol. Plant-Microbe Interact. 23:332-339.

2. Caranta, C., Palloix, A., Lefebvre, V., and Daubèze, A. M. 1997. QTLs for a component of partial resistance to Cucumber mosaic virus in pepper: Restriction of virus installation in host-cells. Theor. Appl. Genet. 94: 431-438.

3. Caranta, C., Pfliege, S., Lefebvre, V., Daubeze, A. M., Thabuis, A., and Palloix, A. 2002. QTLs involved in the restriction of Cucumber mosaic virus (CMV) long-distance movement in pepper. Theor. Appl. Genet. 104:586-591.

4. Chaim, A. B., Grube, R. C., Lapidot, M., Jahn, M., and Paran, I. 2001 Identification of quantitative trait loci associated with resistance to Cucumber mosaic virus in Capsicum annuum. Theor. Appl. Genet. 102:1213-1220.

5. Choi, S. K., Palukaitis, P., Min, B. E., Lee, M. Y., Choi, J. K., and Ryu, K. H. 2005. Cucumber mosaic virus $2 \mathrm{a}$ polymerase and $3 \mathrm{a}$ movement proteins independently affect both virus movement and the timing of symptom development in zucchini squash. J. Gen. Virol. 86:1213-1222.

6. Ding, S. W., Li, W. X., and Symons, R. H. 1995. A novel naturally occurring hybrid gene encoded by a plant RNA virus facilitates long distance virus movement. EMBO J. 14:5762-5772.

7. Hirai S., and Amemiya, Y. 1990. Studies on the resistance of melon cultivars to Cucumber mosaic virus (II) RNA profile of virus multiplied in a resistant and a susceptible cultivars. Ann. Phytopathol. Soc. Jpn. 56:3946.

8. Hong, J. S., Masuta, C., Nakano, M., Abe, J., and Uyeda, I. 2003. Adaptation of Cucumber mosaic virus soybean strains (SSVs) to cultivated and wild soybeans. Theor. Appl. Genet. 107:49-53.

9. Hong, J. S., Ohnishi, S., Masuta, C., Choi, J. K., and Ryu, K. H. 2007. Infection of soybean by Cucumber mosaic virus as determined by viral movement protein. Arch. Virol. 152:321-328.

10. Ji, L. H., and Ding, S. W. 2001. The suppressor of transgene RNA silencing encoded by Cucumber mosaic virus interferes with salicylic acid-mediated virus resistance. Mol. Plant-Microbe Interact. 14:715-724.

11. Jones, J. D. G., and Dangl, J. L. 2006. The plant immune system. Nature 444:323-329.

12. Kang, W. H., Hoang, N. H., Yang, H. B., Kwon, J. K., Jo, S. H., Seo, J. K., Kim, K. H., Choi, D., and Kang, B. C. 2010. Molecular mapping and characterization of a single dominant gene controlling CMV resistance in peppers (Capsicum annuum L.). Theor. Appl. Genet. 120:1587-1596.

13. Kim, C. H., and Palukaitis, P. 1997. The plant defense response to Cucumber mosaic virus in cowpea is elicited by the viral polymerase gene and affects virus accumulation in single cells. EMBO J. 16:4060-4068.

14. Koshimizu, Y., and Iizuka, N. 1958. Soybean stunt disease. Ann. Phytopathol. Soc. Jpn. 23:27. (In Japanese)

15. Li, Q., Ryu, K. H., and Palukaitis, P. 2001. Cucumber mosaic virus-plant interactions: identification of 3 a protein sequences affecting infectivity, cell-to-cell movement, and long-distance movement. Mol. Plant-Microbe Interact. 14:378-385.

16. Lucy, A. P., Guo, H. S., Li, W. X., and Ding, S. W. 2000. Suppression of post-transcriptional gene silencing by a plant viral protein localized in the nucleus. EMBO J. 19:1672-1680.

17. Manly, K. F, Cudmore, R. H., Jr., and Meer, J. M. 2001. Map Manager QTX, cross-platform software for genetic mapping. Mamm. Genome 12:930-932.

18. Manly, K. F., and Olson, J. M. 1999. Overview of QTL mapping software and introduction to Map Manager QT. Mamm. Genome 10:327-334.

19. Masuta, C., Nishimura, M., Morishita, H., and Hataya, T. 1999. A single amino acid change in viral genome-associated protein of Potato virus $Y$ correlates with resistance breaking in 'Virgin A Mutant' tobacco. Phytopathology 89:118-123.

20. Requena, A., Simón-Buela, L., Salcedo, G., and García-Arenal, F. 2006. Potential involvement of a cucumber homolog of phloem protein 1 in the long-distance movement of Cucumber mosaic virus particles. Mol. PlantMicrobe Interact. 19:734-746.

21. Roossinck, M. J., Bujarski, J., Ding, S. W., Hajimorad, R., Hanada, K., Scott, S., and Tousignant, M. 2000. Cucumovirus. Pages 929-930 in: Virus Taxonomy. M. H. V. Van Regenmortel, C. M. Fauquet, D. H. L. Bishop, E. B. Carstens, M. K. Estes, S. M. Lemon, J. Maniloff, M. A. Mayo, D. J. McGeoch, C. R. Pringle, and R. B. Wickner, eds. Academic Press, San Diego, CA.

22. Roossinck, M. J., Zhang, L., and Hellwald, K. H. 1999. Rearrangements in the $5^{\prime}$ nontranslated region and phylogenetic analyses of Cucumber mosaic virus RNA 3 indicate radial evolution of three subgroups. J. Virol. 73:6752-6758.

23. Song, Q. J., Marek, L. F., Shoemaker, R. C., Lark, K. G., Concibido, V. C., Delannay, X., Specht, J. E., and Cregan, P. B. 2004. A new integrated genetic linkage map of the soybean. Theor. Appl. Genet. 109:122-128.

24. Srinivasan, I., and Tolin, S. A. 1992. Detection of three viruses of clovers by direct tissue immunoblotting. (Abstr.) Phytopathology 82:721.

25. Suzuki, M., Kuwata, S., Kataoka, J., Masuta, C., Nitta, N., and Takanami, Y. 1991. Functional analysis of deletion mutants of Cucumber mosaic virus RNA3 using an in vitro transcription system. Virology 183:106-113.

26. Takahashi, H., Miller, J., Nozaki, Y., Sukamto, Takeda, M., Shah, J., Hase, S., Ikegami, M., Ehara, Y., and Dinesh-Kumar, S. P. 2002. RCY1, an Arabidopsis thaliana $R P P 8 / H R T$ family resistance gene, conferring resistance to cucumber mosaic virus requires salicylic acid, ethylene and a novel signal transduction mechanism. Plant J. 32:655-667. 
27. Takahashi, H., Suzuki, M., Natsuaki, K., Shigyo, T., Hino, K., Teraoka, T., Hosokawa, D., and Ehara, Y., 2001. Mapping the virus and host genes involved in the resistance response in Cucumber mosaic virus-infected Arabidopsis thaliana. Plant Cell Physiol. 42:340-347.

28. Takahashi K., Tanaka, T., Iida, W., and Tsuda, Y. 1980. Studies on virus diseases and causal viruses of soybean in Japan. Bull. Tohoku Natl. Agric. Exp. Stn. 62:1-130. (In Japanese)

29. Takanami, Y., Kubo, S., and Imaizumi, S. 1977. Synthesis of single- and double-stranded Cucumber mosaic virus RNAs in tobacco mesophyll protoplasts. Virology 80:376-389.

30. Taliansky, M. E., and Garcia-Arenal, F. 1995. Role of Cucumovirus capsid protein in long-distance movement within the infected plant. J.
Virol. 69:916-922.

31. Yoshii, M., Nishikiori, M., Tomita, K., Yoshioka, N., Kozuka, R., Naito, S., and Ishikawa, M. 2004. The Arabidopsis cucumovirus multiplication 1 and 2 loci encode translation initiation factors $4 \mathrm{E}$ and $4 \mathrm{G}$. J. Virol. 78:6102-6111.

32. Yoshii, M., Yoshioka, N., Ishikawa, M., and Naito, S. 1998. Isolation of an Arabidopsis thaliana mutant in which accumulation of Cucumber mosaic virus coat protein is delayed. Plant J. 13:211-219.

33. Yoshii, M., Yoshioka, N., Ishikawa, M., and Naito, S. 1998. Isolation of an Arabidopsis thaliana mutant in which the multiplication of both Cucumber mosaic virus and Turnip crinkle virus is affected. J. Virol. $72: 8731-8737$ 